\title{
HIGH-TEMPERATURE TRIBOLOGICAL PROTECTION OF LASER CLADDING MATERIALS FOR POWER GENERATION COMPONENTS
}

\author{
Petra ČEJKOVÁ, Antonín KŘíž, Karel BROM, Petr STEIDL \\ University of West Bohemia, Pilsen, Czech Republic, EU \\ LaserTherm spol. s r.o., Vejprnice, Czech Republic, EU
}

https://doi.org/10.37904/metal.2020.3577

\begin{abstract}
The paper examines and compares the properties of laser clad deposits of Stellite 6 and Stellite 21 on 1.4923 + QT base material which is often used for power generation components. Cladding was performed using two different bead widths on a $63 \mathrm{~mm}$ diameter shaft with and without pre-heating. The widths of the beads deposited by a laser welding head were 1 millimetre and 3 millimetres. Using EDX, chemical dilution between the clad beads and the base material was examined. The paper gives a detailed description of metallographic observation of the claddings and the heat-affected zone and correlates the findings with hardness values. It also presents results of wear analysis conducted at simulated service conditions at $550^{\circ} \mathrm{C}$.
\end{abstract}

Keywords: Stellite, cobalt-chromium coatings, laser cladding, wear

\section{INTRODUCTION}

\subsection{Cobalt-chromium coatings}

Cobalt-chromium coatings referred to as stellites are often used in power plants, high-pressure equipment, medicine, military applications and on rotor blades. They were adopted by industry as early as the 19th century. Thanks to their properties, they enhance the performance of parts of ordinary steels. Stellite 6 is the most frequently-used grade of these materials. These materials also contain tungsten and carbon. Base material is normally pre-heated for deposition of these coatings. Typical thickness of such functional coatings is $3-5 \mathrm{~mm}$. As they are relatively expensive due to their chemical composition, they are often deposited as functional coatings rather than used as bulk materials. Flame or laser deposition is used, as it melts the base metal on small scale only. Then the second layer can already possess the desired utility properties. Various stellite coatings find use in various service environments. Normally, these involve elevated temperatures and pressures which impacts the life and performance of the coatings. The coatings may separate from the substrate in service, causing leaks for instance. Those, in turn, lead to both financial and physical losses.

\subsection{Chemical composition of claddings and base material}

Stellite 6 is used for parts operating in large temperature intervals up to $700{ }^{\circ} \mathrm{C}$. It offers favourable sliding characteristics and is therefore applied to sliding joints. Its typical Rockwell hardness is 39-43 HRc.

Table 1 Stellite 6 powder. Manufacturer: Höganas, powder size $45-150 \mu \mathrm{m}$

\begin{tabular}{|l|l|l|l|l|l|l|l|}
\hline Element & $\mathrm{Ni}$ & $\mathrm{Fe}$ & $\mathrm{W}$ & $\mathrm{C}$ & $\mathrm{Mn}$ & $\mathrm{Cr}$ & Co \\
\hline Stellite 6 wt. \% min. & 1.2 & 0.5 & 4.5 & 1.1 & 1 & 28 & 63.7 \\
\hline wt. \% max. & 3 & 3 & 4.8 & 1.2 & 0.4 & 28 & 59.6 \\
\hline
\end{tabular}


Table 2 Stellite 21 powder. Filler material from the manufacturer Oerlikon, powder grain size 45 - $120 \mu \mathrm{m}$ [2]

\begin{tabular}{|l|l|l|l|l|l|l|l|}
\hline Element & $\mathrm{Ni}$ & $\mathrm{Mo}$ & $\mathrm{C}$ & $\mathrm{Cr}$ & $\mathrm{Si}$ & $\mathrm{Fe}$ & Co \\
\hline Stellite 21 wt. \% & 2.8 & 5.7 & 0.21 & 27.9 & 0.5 & 0.1 & 62.17 \\
\hline
\end{tabular}

Stellite 21, unlike Stellite 6, contains no tungsten. It also has a lower carbon level. Stellite 21 was first made in 1930. Immediately, it was adopted for use in medicine as the sliding surface of the functional part of the hip joint. Dispersion of chromium and molybdenum carbides improves hardness at the expense of ductility. The materials exhibits excellent resistance to cavitation. However, when two coatings rub against each other, particles of the stellite coating can be released. Separation of the stellite coating may be related to the deposition method and performance.

The material of the shaft used for the cladding experiment was as follows: Wr.N. 1.4923 +QT (QUENCHED AND TEMPERED)

Table 3 Chemical composition of base material of the shaft

\begin{tabular}{|c|c|c|c|c|c|c|c|c|c|}
\hline Element & C & Si & Mn & $\mathbf{P}$ & $\mathrm{S}$ & $\mathrm{Cr}$ & $\mathrm{Ni}$ & Mo & V \\
\hline $\begin{array}{l}1.4923+Q T \\
\text { wt. } \%\end{array}$ & $\begin{array}{l}0.18- \\
0.24\end{array}$ & $\begin{array}{l}\text { Max. } \\
0.5\end{array}$ & $\begin{array}{l}0.4 \\
0.9\end{array}$ & $\begin{array}{l}\max . \\
0.025\end{array}$ & $\begin{array}{l}\text { Max. } \\
0.015\end{array}$ & $\begin{array}{l}11.0 \quad- \\
12.5\end{array}$ & $\begin{array}{l}0.3- \\
0.8\end{array}$ & $\begin{array}{l}0.8- \\
1.2\end{array}$ & $\begin{array}{l}0.25 \\
0.35\end{array}$ \\
\hline
\end{tabular}

\subsection{Laser cladding of Stellite 6 and Stellite 21}

Stellite coatings have been deposited by welding for decades. Advancement of technology led to more productive deposition techniques and to methods which caused less disturbance to the base material, such as laser cladding. In power generation industry, specifically in weld cladding of turbine parts, difficulties arose in deposition of Stellite 6 on steam turbine shafts. Thermal loading led to separation of the cladding from the base material. The likely causes were the stress generated by the thermal gradient during cladding and sub-optimal chemical composition due to which tungsten carbides formed at elevated temperatures. Another drawback was the need for pre-heating for cladding. In this experimental study, specimens were produced by cladding using a narrow welding head which deposited beads $1 \mathrm{~mm}$ in width and a wide welding head for $3 \mathrm{~mm}$ beads. Cladding was performed with and without pre-heating. The goal was to compare the levels of dilution, the size of the HAZ and hardness for these different conditions. In addition, wear tests at $550^{\circ} \mathrm{C}$ were carried out. Twolayer claddings were examined.

The cladding parameters were as follows: laser power $4 \mathrm{~kW}$, cladding speed approx. $120 \mathrm{~m} / \mathrm{min}$, protective argon gas 5.0. The interpass temperature for runs with pre-heating was $450^{\circ} \mathrm{C}$.

Table 4 Summary of designations of specimens selected for analysis, the colour coding with identical colours indicates specimens to be compared

\begin{tabular}{|l|l|l|l|l|l|}
\hline $\begin{array}{c}\text { Full designation of } \\
\text { specimen }\end{array}$ & $\begin{array}{c}\text { Specimen } \\
\text { number: }\end{array}$ & $\begin{array}{c}\text { Cladding } \\
\text { material }\end{array}$ & $\begin{array}{c}\text { Pre-heating-P } \\
\text { No pre-heating-B }\end{array}$ & $\begin{array}{c}\text { Number of } \\
\text { cladding layers }\end{array}$ & Cladding \\
\hline 2 S21 P2S & 2. & Stellite 21 & P - pre-heating & 2 & S - wide head \\
\hline 11 S21 B2S & 11. & Stellite 21 & B-no pre-heating & 2 & S-wide head \\
\hline 13 S6 B2S & 13. & Stellite 6 & B-no pre-heating & 2 & S-wide head \\
\hline 17 S6 B2U & 17. & Stellite 6 & B -no pre-heating & 2 & U-narrow head \\
\hline 18 S21B2U & 18. & Stellite 21 & B -no pre-heating & 2 & U-narrow head \\
\hline
\end{tabular}

The company Lasertherm produced 18 different claddings [3], as shown in Figure 1. The differences between them included the cladding material, the use of pre-heating and the bead width. Four specimens were selected for analysis: 2S21P2S, 11S21P2S, 13 S6 B2S and 18 S6 B2U, as listed in Table 3. 

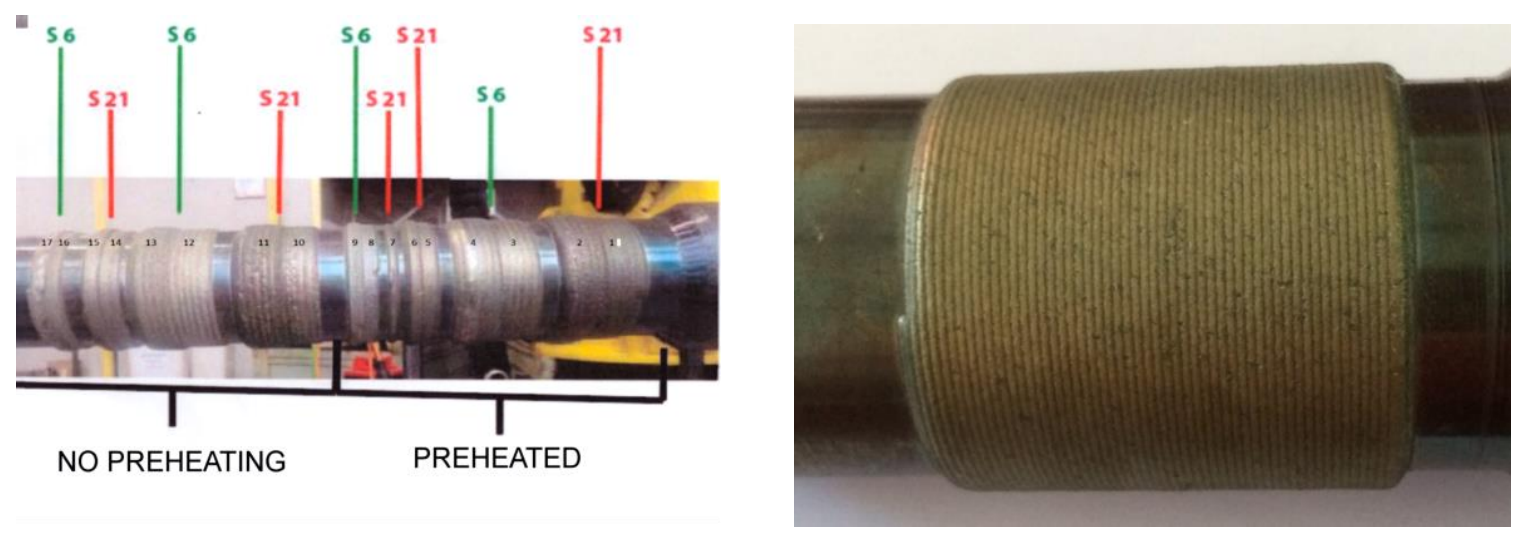

Figure 1 Left: photograph of a shaft with laser claddings S6 and S21 (Stellite 6 and Stellite 21), right: specimen 18 of Stellite 21, detail, narrow bead of $1 \mathrm{~mm}$ deposited without pre-heating

\subsection{Microhardness of laser cladding and HAZ in the base material}

On all the selected samples, microhardness number HV0.1 was measured. Figure 2 shows depth profiles of hardness from the cladding surface toward the base material. In Stellite 6, microhardness is slightly higher than in Stellite 21. The presence of tungsten carbides contributes to it. The plots show that the HAZ is a transition region for hardness which changes from the value $400 \mathrm{HV} 0.1$ in the cladding to $600 \mathrm{HV} 0,1$ in the HAZ. The specimens in Figure 2 identified as 2S21P2S - with pre-heating, 11S21B2 - no pre-heating and 13 S6 B2S - no pre-heating exhibit very similar hardness profiles. Specimen 18 S6 B2U - no pre-heating, has a step change between the HAZ and the base material. [4]

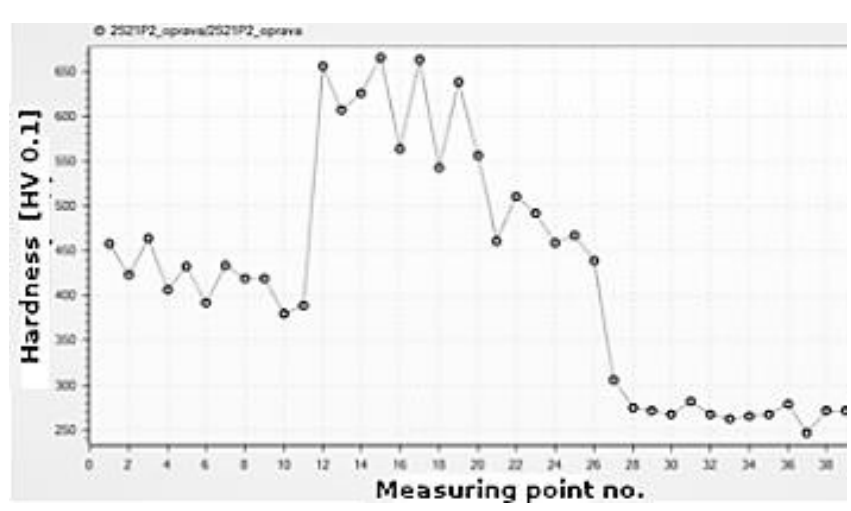

Specimen 2S21P2S - with pre-heating

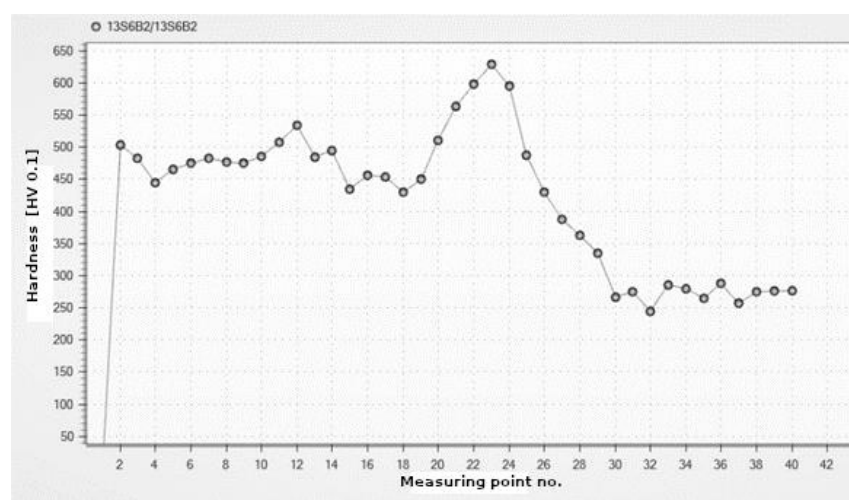

Specimen 13 S6 B2S - no pre-heating

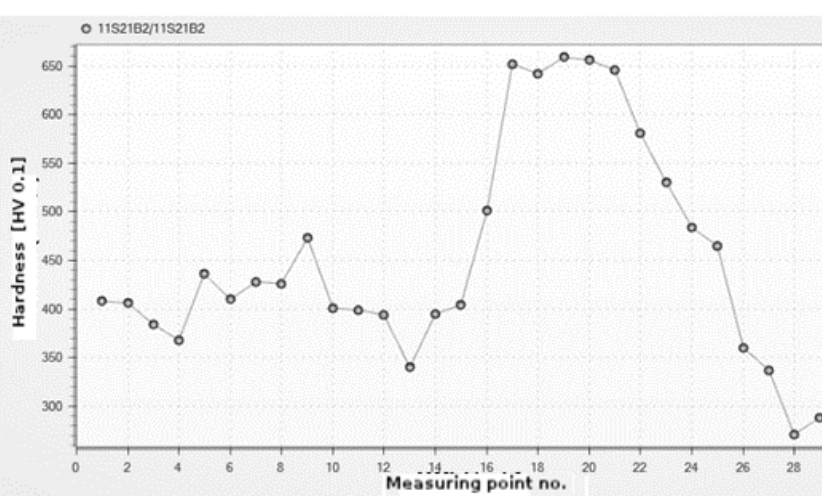

Specimen 11S21B2 - no pre-heating

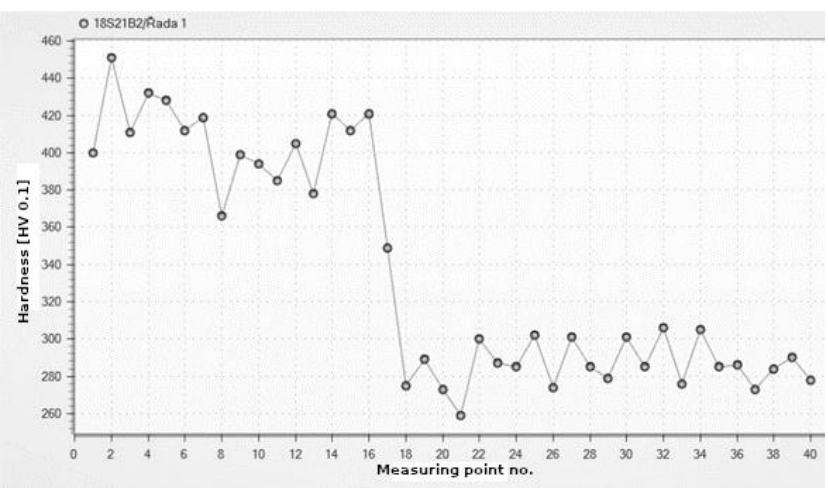

Specimen 18 S21 B2U - no pre-heating

Figure 2 Hardness profiles HV0.1 in specimens 2S21P2S, 11S21P2S, 13 S6 B2S and 18 S21 B2U 


\subsection{Metallographic characterization of laser cladding}

\subsubsection{Macroscopic observation of Stellite 21 and Stellite 6 laser claddings}

Macrostructure in Figure 3 show two-layer claddings. Stellite 6 is on the left, Stellite 21 on the right. Etching has revealed the different microstructures in them. No cracks or lack of penetration can be seen in the micrographs. They show the structure of the bead produced by the Marangoni convection in the melt pool.
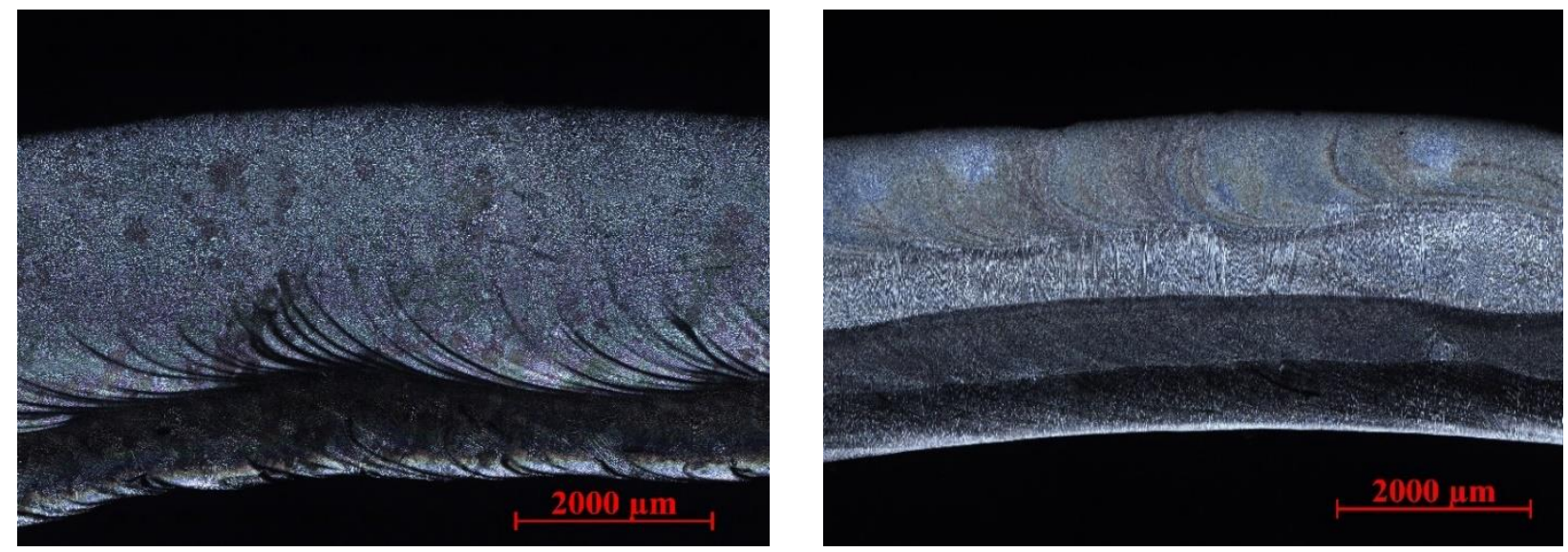

Figure 3 Macropicture of laser cladding, etched, magnification 20x, left: Stellite 6, right: Stellite 21.

\subsubsection{Microscopic observation of Stellite laser cladding}

Two specimens were selected for scanning electron microscopic observation: 2S21P2 and 18S21B2 in order to identify differences between the claddings and dilution patterns produced with and without pre-heating. Both specimens were laser clad with two layers of Stellite 21. Specimen 2S21P2 was prepared with the use of preheating at $450^{\circ} \mathrm{C}$. Figure 4, left, is a microstructure of the cladding surface on specimen 2S21P2. There is an oxide layer which was also confirmed by chemical analysis. Globular particles of incompletely melted powder can be seen. The surface of the cladding is to be removed by grinding. These oxides will therefore be removed before the shaft is put into operation. Figure 4, right, is a detail of specimen 18S21B2. It shows a region where grain boundaries became melted in the base material. This fusion region can be traced to a depth of 80 micrometres below the surface of the base material. After pre-heating and cladding, the depth of fusion was 96 micrometres. Without pre-heating, the depth was 80 micrometres.
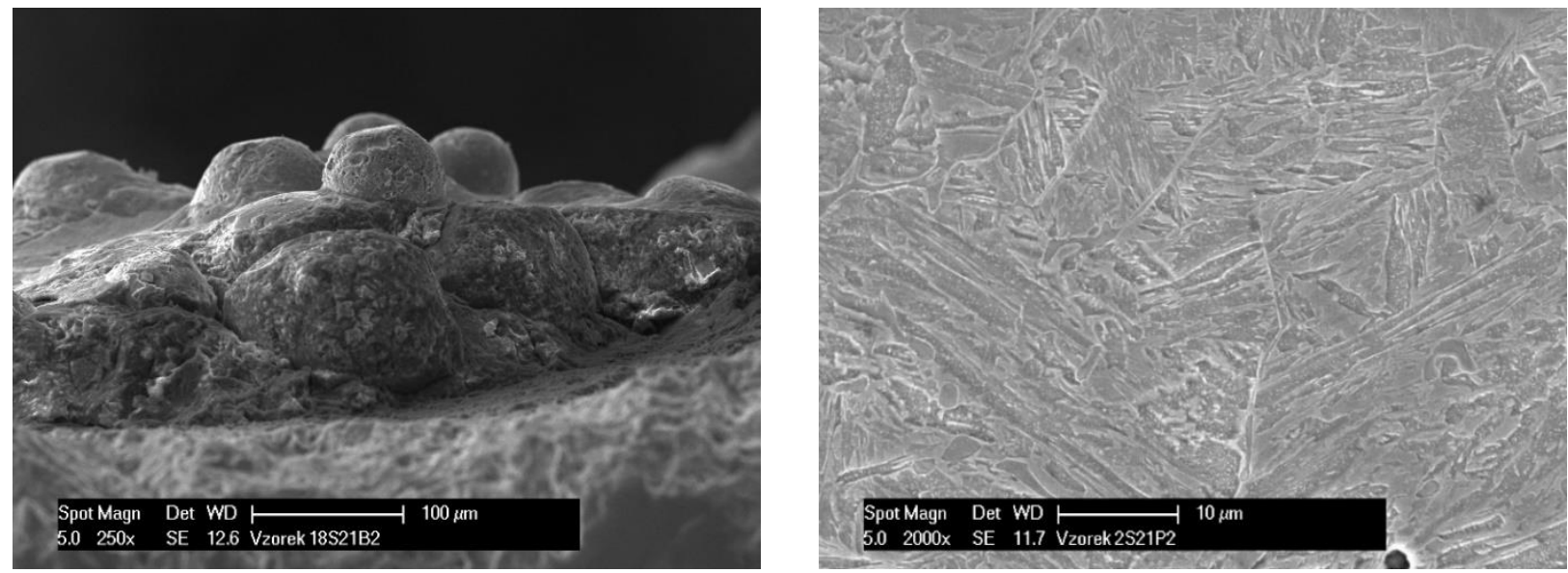

Figure 4 Specimen 2S21P2 - chemical composition of V2P11 at 46 micrometres below the cladding in the base material - melting at grain boundaries is visible. 


\subsection{Determining the dilution of the base material and the cladding}

Chemical dilution between the cladding and base material:

Table 5 Chemical dilution in specimen 18S21B2 - Stellite 21

\begin{tabular}{|l|l|l|l|l|l|l|l|l|l|}
\hline $\begin{array}{l}\text { Specimen } \\
\text { 18S21B2 }\end{array}$ & V18B1 & V18B1a & V18B6 & V18B7 & V18B8 & V18B9 & V18B10 & V18B11 & V18B13 \\
\hline $\mathrm{O}$ & & 9.60 & 4.45 & 3.98 & 3.42 & 3.26 & 3.33 & 2.77 & 3.11 \\
\hline $\mathrm{Al}$ & 1.30 & 2.10 & 0.73 & 1.07 & 0.10 & 0.21 & 0.06 & 0.35 & 0.75 \\
\hline $\mathrm{Si}$ & 2.50 & 2.90 & 0.89 & 0.96 & 0.47 & 0.65 & 0.50 & 0.44 & 0.69 \\
\hline $\mathrm{Mo}$ & 4.50 & 4.70 & 6.54 & 6.41 & 3.87 & 4.3 & 4.76 & 1.14 & 1.74 \\
\hline $\mathrm{Cr}$ & 23.50 & 22.40 & 23.66 & 24.14 & 18.91 & 19.75 & 21.62 & 11.6 & 11.28 \\
\hline $\mathrm{Mn}$ & 1.30 & 0.90 & 0.51 & 0.51 & 0.59 & 0.82 & 0.79 & 0.71 & 0.84 \\
\hline $\mathrm{Fe}$ & 1.40 & 2.03 & 6.05 & 6.03 & 36.97 & 32.27 & 23.65 & 81.75 & 80.91 \\
\hline $\mathrm{Co}$ & 52.80 & 52.30 & 53.96 & 53.56 & 34.00 & 36.46 & 42.62 & 0.84 & 0.27 \\
\hline $\mathrm{Ni}$ & 3.50 & 3.10 & 3.34 & 3.34 & 1.68 & 2.28 & 2.65 & 0.39 & 0.42 \\
\hline
\end{tabular}

Table 6 Chemical dilution in specimen 18S21B2 - Stellite 21

\begin{tabular}{|l|l|l|l|l|l|l|l|l|l|l|}
\hline Specimen 2S21P2 & V2P1 & V2P4 & V2P5 & V2P6 & V2P7 & V2P8 & V2P9 & V2P11 & V2P13 & V2P14 \\
\hline $\mathrm{O}$ & 6.47 & 5.74 & 12.65 & 5.39 & 5.13 & 5.09 & 5.44 & 4.09 & 4.05 & 4.17 \\
\hline $\mathrm{Al}$ & 0.93 & 0.62 & 1.63 & 0.42 & 0.46 & 0.47 & 0.44 & 0.16 & 0.56 & 0.19 \\
\hline $\mathrm{Si}$ & 1.06 & 1.06 & 5.12 & 1.01 & 0.89 & 0.98 & 0.97 & 0.61 & 0.66 & 0.67 \\
\hline $\mathrm{Mo}$ & 8.00 & 7.22 & 4.42 & 7.54 & 7.02 & 6.93 & 7.21 & 1.79 & 1.44 & 1.75 \\
\hline $\mathrm{Cr}$ & 23.04 & 22.68 & 20.48 & 22.85 & 23.56 & 23.25 & 22.68 & 11.35 & 11.18 & 11.41 \\
\hline $\mathrm{Mn}$ & 0.59 & 0.46 & 1.16 & 0.52 & 0.51 & 0.47 & 0.43 & 0.62 & 0.68 & 0.72 \\
\hline $\mathrm{Fe}$ & 5.03 & 12.79 & 10.77 & 12.18 & 10.54 & 12.19 & 13.4 & 80.38 & 80.82 & 80.47 \\
\hline $\mathrm{Co}$ & 52.00 & 46.88 & 41.56 & 47.58 & 49.24 & 48.02 & 46.92 & 0.69 & 0.28 & 0.35 \\
\hline $\mathrm{Ni}$ & 2.88 & 2.57 & 2.21 & 2.51 & 2.66 & 2.06 & 2.51 & 0.29 & 0.33 & 0.27 \\
\hline
\end{tabular}

\subsection{Wear resistance determined by pin-on-disk test}

The goal of the test was to assess the wear resistance of four specimens. One test was performed on each of them. Stellite-clad specimens no. 13S6B2, 18S21B2, 11S21B2 and 2S21P2 were specially prepared for pinon-disk testing of wear resistance. The test was performed at $550^{\circ} \mathrm{C}$, which is the service temperature of these materials.

\subsubsection{Test arrangement}

The purpose of the test was to find the wear resistance of the materials at elevated temperature. This test is based on pressing a spherical-end tool of a specific diameter by a defined force into a (planar) test surface of a specimen which rotates at a specified speed. The indenter is loaded by a prescribed force exerted by a weight and attached to a rigid arm. Strain gauges fitted to the arm record the resulting friction force. The wear rate of the material is found by examining the wear track created by the indenter in the surface. The measured parameters include the actual amount of wear (material loss) and the impression (deformation) in the test specimen. This simple method allows friction and wear to be studied using contact between two surfaces of virtually any materials, either dry or lubricated. The measurement is evaluated using the powerful TriboX software. Wear resistance is expressed as wear rate. Wear rate is calculated from the wear volume, load and 
total path of the relative movement of the indenter and the specimen. The equation is given below. The cross section (which indicates the areal loss) of the wear track (produced by the indenter) is evaluated using SURTRONIC 25 contour measuring machine. [5]

Calculation of wear rate in the test specimen: $\quad W=\frac{\text { Wear volume }\left[\mathrm{mm}^{3}\right]}{\text { Load }[\mathrm{N}] \cdot \text { Path }[\mathrm{m}]}\left[\mathrm{mm}^{3} / \mathrm{Nm}\right]$

\subsubsection{Test parameters and conditions}

Pin-on-disk test was performed under the following conditions on each of the specimens: temperature $550{ }^{\circ} \mathrm{C}$, load $10 \mathrm{~N}$, number of cycles $5000, \mathrm{Al}_{2} \mathrm{O}_{3}$ indenter, total path $94.25 \mathrm{~m}$, speed of 80 revolutions/minute, the relative linear speed at the point of contact: $25 \mathrm{~mm} / \mathrm{s}$. On each specimen, the test took one hour.

\subsubsection{Wear resistance}

The measurements on tested specimens are listed in Table 8. Plots of wear rates and mean friction coefficients are given in Figure 5. The mean friction coefficient was found as an average from all data for the entire test, i.e. from hundreds of thousand of values.

Table 7 Wear rates at $550^{\circ} \mathrm{C}$

\begin{tabular}{|l|l|l|l|l|l|l|l|l|l|}
\hline Specimen & $\begin{array}{c}\text { Area } \\
{[\mu \mathrm{m} 2]}\end{array}$ & $\begin{array}{c}\text { Standard } \\
\text { deviation } \\
\text { of area } \\
{[\mu \mathrm{m} 2]}\end{array}$ & $\begin{array}{c}\text { Wear } \\
\text { volume } \\
{[\mu \mathrm{m} 3]}\end{array}$ & $\begin{array}{c}\text { Wear } \\
\text { rate } \\
{[\mu \mathrm{m3} /} \\
\mathbf{N m}]\end{array}$ & $\begin{array}{c}\text { Wear rate } \\
{[\mathbf{1 0 - 6 m m 3 /}} \\
\mathbf{N m}]\end{array}$ & $\begin{array}{c}\text { Mean } \\
\text { friction } \\
\text { coefficient }\end{array}$ & $\begin{array}{c}\text { Track } \\
\text { width } \\
{[\mathrm{mm}]}\end{array}$ & $\begin{array}{c}\text { Track } \\
\text { depth } \\
{[\mu \mathrm{m}]}\end{array}$ & $\begin{array}{c}\text { Track } \\
\text { depth } \\
{[\mathrm{mm}]}\end{array}$ \\
\hline 13S6B2 & 5754 & 268 & 108457989 & 115075 & 115.075 & 0.50 & 0.9 & 13 & 0.013 \\
\hline 18S21B2 & 5861 & 253 & 110470179 & 117210 & 117.210 & 0.45 & 0.7 & 15 & 0.015 \\
\hline 11S21B2 & 6263 & 286 & 118047700 & 125250 & 125.250 & 0.35 & 0.7 & 16 & 0.016 \\
\hline 2S21P2 & 5700 & 207 & 107435400 & 113990 & 113.990 & 0.36 & 0.7 & 15 & 0.015 \\
\hline
\end{tabular}

The area $\left[\mu \mathrm{m}^{2}\right]$ displaced by the indenter as measured on individual specimens using SURTRONIC 25 is given in Table 8. Areal loss was evaluated by means of TriboX software. The final area value was an average from eight values measured along the entire circular track. Standard deviation of the area value (2nd column in Table 8) is the smallest for 2S21P2 and largest for $11 \mathrm{~S} 21 \mathrm{~B} 2$. The wear on the $\mathrm{Al}_{2} \mathrm{O}_{3}$ ball indenters was negligible.

The highest wear resistance was found in 2S21P2. Specimen 13S6B2 showed a very similar value. The lowest resistance was found for 11S21B2. However, the difference from the other specimens was less than $10 \%$. The friction coefficient was in the range from 0.35 to 0.50 . The specimens under test are shown in the photograph in Figure 6.

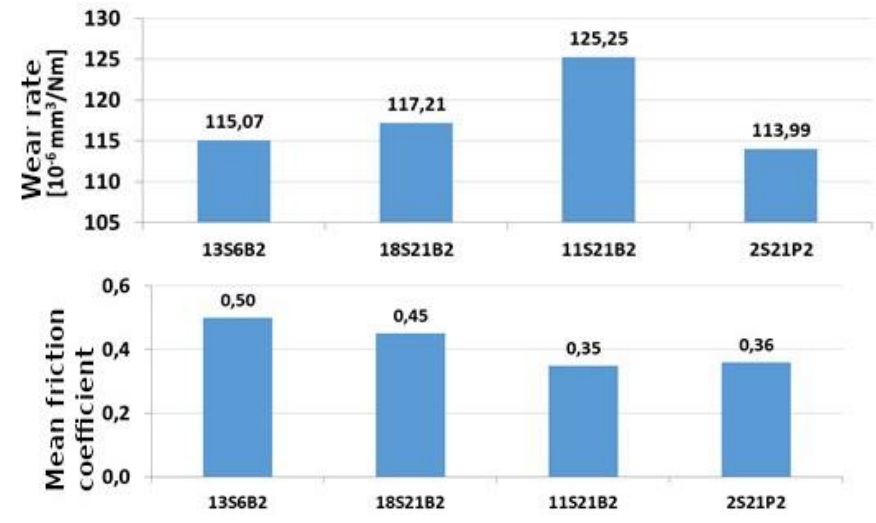

Figure 5 Plots comparing the wear rate (left) and mean friction coefficient (right) 
Table 8 Areal loss in pin-on-disk test [ $\left.\mu \mathrm{m}^{2}\right]$

\begin{tabular}{|l|l|}
\hline 13S6B2 & Area \\
\hline 1 & 5493 \\
\hline 2 & 5725 \\
\hline 3 & 5912 \\
\hline 4 & 6222 \\
\hline 5 & 5389 \\
\hline 6 & 5538 \\
\hline 7 & 6040 \\
\hline 8 & 5712 \\
\hline Diameter & 5754 \\
\hline
\end{tabular}

\begin{tabular}{|l|l|}
\hline 18S21B2 & Area \\
\hline 1 & 6096 \\
\hline 2 & 5600 \\
\hline 3 & 5859 \\
\hline 4 & 6231 \\
\hline 5 & 5400 \\
\hline 6 & 5790 \\
\hline 7 & 5866 \\
\hline 8 & 6043 \\
\hline Diameter & 5861 \\
\hline
\end{tabular}

\begin{tabular}{|l|l|}
\hline 11S21B2 & Area \\
\hline 1 & 5860 \\
\hline 2 & 6286 \\
\hline 3 & 6901 \\
\hline 4 & 6054 \\
\hline 5 & 6377 \\
\hline 6 & 6309 \\
\hline 7 & 6135 \\
\hline 8 & 6179 \\
\hline Diameter & 6263 \\
\hline
\end{tabular}

\begin{tabular}{|l|l|}
\hline 2S21P2 & Area \\
\hline 1 & 5604 \\
\hline 2 & 5556 \\
\hline 3 & 5376 \\
\hline 4 & 5728 \\
\hline 5 & 5932 \\
\hline 6 & 5561 \\
\hline 7 & 5783 \\
\hline 8 & 6057 \\
\hline Diameter & 5700 \\
\hline
\end{tabular}

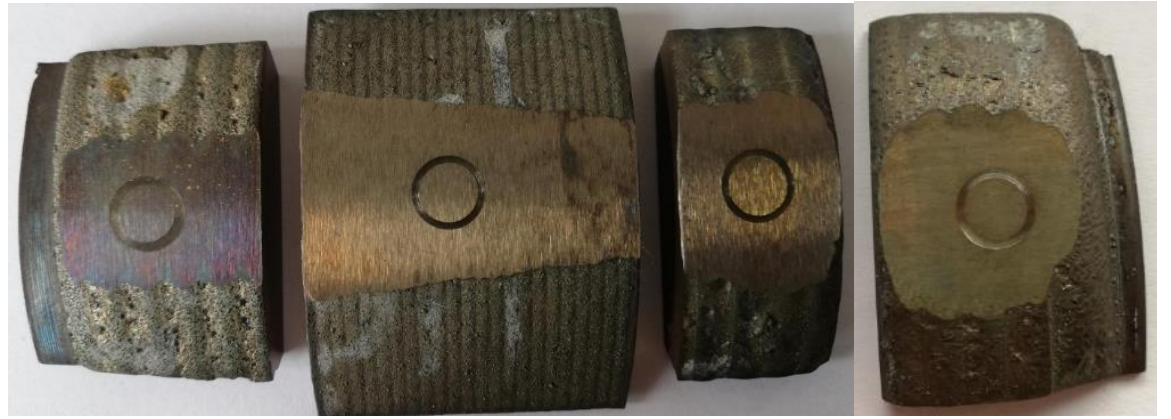

Figure 6 Specimens after wear testing - 13S6N2 (left), 18S21B2 (centre - left), 11S21B2 (centre-right), 2S21P2 (right)

Pin-on-disk testing was performed at $550{ }^{\circ} \mathrm{C}$, which is the material's actual service temperature. Four Stellite 6 and 21 claddings have been tested. The tests have shown substantial similarity among the claddings, as the differences were on the order of several percentage points. The highest wear resistance was found in 2S21P2 and 13S6B2, whereas the lowest values were found in 11S21B2. The mean friction coefficient was between 0.35 and 0.50 . To obtain more relevant assessment of wear resistance, it is recommended to run longer tests and repeat them.

\section{CONCLUSION}

An analysis of several laser claddings of Stellite 6 and Stellite 21 deposited in both wide and narrow beads confirmed the viability of substitution of Stellite 6 with Stellite 21. The former is ordinarily used for cladding shafts for power generation equipment. The main benefit of deposition of narrow beads is the economic one, which includes the cladding speed. Using this method, one operation could be omitted: pre-heating the base material to $450{ }^{\circ} \mathrm{C}$. However, this should be confirmed by testing multiple specimens or by field tests. The key requirement placed by customers on the wear performance of this coating was experimentally validated under service conditions involving the temperature of $550{ }^{\circ} \mathrm{C}$. Wear test results were comparable for Stellite 6 and Stellite 21 . When compared to Inconel claddings, Stellite claddings deliver $30 \%$ higher wear resistance.

\section{ACKNOWLEDGEMENTS}

This article was made possible by the funding for the SGS-2018-051 project "Application of new treatment and test procedures to surfaces and bulk materials for improved usability of assemblies and work tools in industry". 
The above findings were achieved thanks to support from MPO project no. FV20226 „Laserová technologie pro aditivní a hybridní výrobu z kovü" (Laser Technology for Additive and Hybrid Metal Manufacturing).

\section{REFERENCES:}

[1] HÖGANÄS. Data sheet issued by the company HÖGANÄS [Online]. 2020 [vieved 2020]. Available from: https://www.hoganas.com/en/powder-technologies/.

[2] OERLIKON MANAGEMENT AG. Data sheet issued by the company Oerlikon [Online]. 2020 [vieved 2020]. Available from: https://www.oerlikon.com/en/.

[3] LASERTHERM. Company data from Lasertherm [Online]. 2020 [vieved 2020]. Available from: https://www.lasertherm.cz/.

[4] KLUFOVÁ PAVLA. Resistance to degradation of austenitic laser clads deposit. Dissertation. 2018. Dissertation. University of West Bohemia.

[5] STACHOWIAK, G. W. a A. W. BATCHELOR. Engineering tribology. Fourth edition. Oxford: Elsevier/ButterworthHeinemann, 2014. [Online]. [vieved 2019-08-30]. Available from:

https://app.knovel.com/hotlink/toc/id:kpETE00005/engineering-tribology/engineering-tribology. 